Article

\title{
Why Defend Something I Don't Agree with? Conflicts within the Commission and Legislative Amendments in Trilogues
}

\author{
Thomas Laloux ${ }^{1, *}$ and Lara Panning ${ }^{2}$ \\ ${ }^{1}$ Institute of Political Science Louvain-Europe, UCLouvain, Belgium; E-Mail: thomas.g.laloux@uclouvain.be \\ 2 Department of Political Science, University of Bamberg, Germany; E-Mail: lara.panning@uni-bamberg.de \\ * Corresponding author
}

Submitted: 6 February 2021 | Accepted: 18 June 2021 | Published: 30 July 2021

\begin{abstract}
This article aims to examine the effect of intra-institutional conflicts in the European Commission on the extent of changes made to legislative proposals in trilogue negotiations. We develop and test three hypotheses related to how conflicts within the Commission, namely that intra-institutional disagreements during policy formulation (h1), and potential conflicts with previous (h2) or subsequent (h3) colleges of commissioners, increase the number of amendments to the Commission's proposal adopted in trilogues. To test our hypotheses, we use a new dataset measuring the number of changes between Commission proposals and adopted legislation for 216 legislative acts negotiated between 2012 and 2019 by means of text-mining techniques. It is important to note that we control for differences between the Commission's proposals and the co-legislators' positions in order to distinguish between an effect on preferences anticipation and on the negotiations proper. Our results indicate that intra-institutional conflicts affect the Commission's anticipation of the co-legislators' positions. The effect on its behaviour in trilogues, that is, after the legislative proposal has been tabled, is less clear. Regarding the latter, only the number of Directorates-General involved is significantly linked with the number of amendments tabled. These findings suggest that while intra-institutional disagreements affect the Commission's role in trilogues, the range of preferences is more important than the intensity of conflicts.
\end{abstract}

\section{Keywords}

bargaining success; college; delegation; European Commission; intra-institutional conflicts; legislative decision-making; text-mining; trilogues

Issue

This article is part of the issue "Resilient Institutions: The Impact of Rule Change on Policy Outputs in European Union Decision-Making Processes" edited by Ariadna Ripoll Servent (University of Salzburg, Austria) and Angela Tacea (Vrije Universiteit Brussel, Belgium).

(C) 2021 by the authors; licensee Cogitatio (Lisbon, Portugal). This article is licensed under a Creative Commons Attribution 4.0 International License (CC BY).

\section{Introduction}

The European Commission (henceforth referred to as the Commission) is composed of multiple services, Directorates-General (DGs) and 27 commissioners, who may have different policy preferences. Yet, the college of commissioners (College), as the highest political level in the Commission, adopts legislative proposals collegially. This principle of collegiality implies collective decision-making, which, in the case of disagreement within the College, most likely results in compromise decisions (Ershova, 2019; Wonka, 2008). In other words, the resulting proposals do not correspond exactly to the preferences of every commissioner. Nevertheless, because of the principle of collegiality, all commissioners are collectively responsible for College decisions. These Commission proposals, agreed in the College, constitute the basis for legislative negotiations in trilogues between the European Parliament, the Council of the European Union (in the following, simply referred to as the Parliament and the Council), and the Commission. 
The Parliament and the Council, having the formal decision-making right, usually modify the Commission's proposal, whereas the Commission is present to defend its proposal and foster a deal. Generally, one lead commissioner is responsible for representing the Commission in these meetings. Hence, in the case of disagreement within the College, this commissioner must defend a proposal with which they might not fully agree. This raises the question of whether they do so properly. For example, the commissioner could try to promote their own preferences or simply not defend a provision they do not support. In this article we aim to address this issue by focusing on the following questions: Do intra-institutional conflicts in the Commission impact the behaviour of its representatives in trilogue negotiations in a way that leads to an increasing number of amendments adopted by Council and Parliament broadly speaking? We assume that the lead commissioner-who represents the Commission in trilogueshas less incentive to defend proposals with which they potentially disagree, leading to more amendments.

When analysing European Union (EU) legislative negotiations, including trilogues, existing research usually treats the Commission as a unitary actor instead of taking its various intra-institutional actors and preferences into account (Gastinger, 2017; Rauh, 2020). Conflicts and disagreements between commissioners, however, are likely to arise during the procedure that leads to a legislative proposal. We expect these disagreements to spill over into inter-institutional negotiations. As previous research has shown, intra-institutional conflicts are an important factor in explaining the EU institutions' (in)ability to defend their preferences in negotiations (Costello \& Thomson, 2013; Tsebelis, 2002). Yet, little is known about their impact on the Commission's role, that is on the behaviour of its representatives in the legislative process, although the Commission participates in all steps of inter-institutional legislative negotiations. This lack of knowledge when it comes to factors influencing the Commission's role in trilogues may seem surprising but is consistent with 'the near total absence of any discussion of [the Commission's] role in the spate of recent analyses of early agreements' (Kreppel, 2018, p. 16).

Against this backdrop, this article aims to examine the effects of intra-institutional conflicts in the Commission on the extent of changes made to legislative proposals, the present article helps to fill this research gap. To that end, we develop and test three hypotheses related to disagreements within the Commission: intrainstitutional conflicts during policy formulation (h1), and potential conflicts with the previous (h2) or subsequent (h3) College. To test our hypotheses, we use a new dataset measuring the number of changes between Commission proposals and adopted legislation for 216 legislative acts negotiated between 2012 and 2019.

By examining whether the Commission's intrainstitutional policy has an impact on the results of the
EU legislative procedure, we help fill two gaps in the current literature. First, existing research shows that decision-making dynamics within the Commission vary from file to file (Rauh, 2020; Van Ballaert, 2017), and that intra-institutional conflicts can arise in this process (Hartlapp et al., 2014; Rauh, 2019). The way in which a proposal is prepared and adopted affects its content (Bürgin, 2017; Hartlapp et al., 2014), the time for adoption (Chalmers, 2014; Rasmussen \& Toshkov, 2013), the Commission's ability to correctly foresee the co-legislators' preferences (Bunea \& Thomson, 2015), or the level of discretion granted for the implementation of the adopted legislation (Ershova, 2019). Therefore, intrainstitutional dynamics and conflicts can affect legislative decision-making. Yet, despite these findings, we know little about whether the Commission's intra-institutional decision-making processes have consequences for the fate of legislative proposals that result from these very same processes.

Second, we know little about the Commission's behaviour in trilogues and potential consequences for the legislative process following from this behaviour. While the Commission's relevance in legislative negotiations is debated, the few articles that examine the Commission in trilogues compare legislative files negotiated in trilogues with files that follow the formal procedure outside of trilogues (Cross \& Hermansson, 2017; Hartlapp et al., 2013; Kreppel, 2018). With trilogues nowadays being the main fora of legislative negotiations, these comparisons become less relevant to understand the current EU legislative decision-making, since almost all co-decision files are negotiated in trilogues (Kluger Dionigi \& Koop, 2017). Therefore, research on the Commission's behaviour and influence in trilogues needs to continue outside of such comparisons.

From this perspective, this article contributes empirically to the debates regarding the Commission's power vis-à-vis the Parliament and the Council by indirectly testing whether and when the Commission matters in trilogues. If the intra-institutional decision-making of the Commission is important for the outcome of trilogues, this would suggest that what happens intrainstitutionally in the Commission is an important factor to understand the outcomes of inter-institutional negotiations and, consequently, that it might have power therein. In other words, if the Commission's intrainstitutional dynamics influence the negotiations, the Commission's preferences may be an important factor to understand the dynamics that lead to the trilogue agreement. If the Commission's substantive preferences do not matter for trilogues, its representatives should only be able to play a mediator role between the two co-legislators, not defending their own position on the legislation. If so, the internal dynamics would have no impact on the fate of the proposal after it has been issued. In contrast, we find that quarrels within the Commission can affect the outcome of the negotiations between the co-legislators, which is possible insofar 
as the Commission representatives are able to defend their preferences, to some extent, against the will of the co-legislators.

Addressing those gaps therefore contributes to a better understanding of both the EU legislative process, especially trilogues, and the Commission's intrainstitutional politics. In line with the overall aim of this special issue, we examine how the change of informal rules that lead to the systematic use of trilogues (instead of following the formal legislative procedure) affects the Commission. As this development affected intra- and inter-institutional dynamics between the co-legislators (Laloux, 2020), the same should be true for the Commission, yet it remains unclear.

Of course, other factors can influence the Commission's behaviour in trilogues as well. If the file under negotiation is, for example, a priority file of the Commission's work programme, the Commission might be more likely to push for its own positions, trying to limit the co-legislator's amendments to the text. Moreover, external factors could also affect trilogues and the Commission's behaviour therein. If, for example, public attention to a file increases due to a political crisis, more pressure might be put on all negotiating parties. These are noteworthy limitations of this study, and, as such, they must be taken into account when considering it. However, while it is to be expected that such factors have an effect on the Commission's behaviour and influence as well, it is likely that they do not contradict but interact with our findings. Our results thus pave the way for future research to analyse the behaviour and effect of the Commission in trilogues.

The article is structured as follows: The next section provides an overview of trilogues with a focus on the role of the Commission therein. Before presenting the data set, Section 3 develops our hypotheses based on the literature on the intra-institutional functioning of the Commission. The article concludes with a presentation of the empirical results in Section 5, and a summary of the main arguments and findings.

\section{Who Influences What? The Commission in Trilogues}

In the EU, almost all legislative files are adopted under the ordinary legislative procedure (OLP), which requires the Parliament and the Council to agree on a common text based on a Commission proposal. Almost all legislative negotiations between these institutions to reach a common text are now conducted in informal meetings called 'trilogues' by a small group of representatives of the three institutions at the earliest stage of the OLP (Laloux, 2020; Ripoll Servent \& Panning, 2019). In terms of legislative decision-making, trilogues have thus become the standard way of negotiating in the $\mathrm{EU}$, so that nowadays, the vast majority of legislation is thus adopted early on in the process (either at first or early second reading) on the basis of informal compromises. To put it plainly, there is hardly any legisla- tion under the OLP that is not adopted early. The only files that do not go through trilogues are those that do not require negotiations for there is no disagreement (Kluger Dionigi \& Koop, 2017). The Parliament's activity report on the 8th parliamentary term substantiates the importance of trilogues in EU legislation: Among the 401 OLP files adopted and signed between 2014 and 2019, '1,185 trilogues took place at different stages of the legislative procedure (first, early second and second reading)' (European Parliament, 2019, p. 8).

In all of these negotiations, the Commission is always present. Its trilogue delegation usually consists of officials 'always at a high level of hierarchy...together with support staff' (Roederer-Rynning \& Greenwood, 2015, p. 1155). The main role of these Commission representatives in trilogues is to facilitate a compromise between the positions of the Parliament and the Council (Burns, 2014; Nugent \& Rhinard, 2019). However, little is known about the Commission in trilogues beyond that. While the impact of trilogues on the Commission-although analysed in the literature-remains unclear, the impact of the Commission on trilogue negotiations is largely unknown. More generally, the fact that the Commission has no formal decision-making power over EU legislation has prompted debates about its role and influence in legislative negotiations (Rasmussen, 2012). Two opposing positions have been taken in the literature regarding the Commission's role in trilogues.

On the one hand, some recognize the Commission as an important actor in EU legislative negotiations (Becker et al., 2016; Nugent \& Rhinard, 2019). Not only does the Commission have its own policy preferences distinct from the co-legislators (Fuglsang \& Olsen, 2009; Thomson, 2011), but it also has several resources to defend them and exert influence during negotiations (Nugent \& Rhinard, 2016). For example, it can withdraw its proposal (Nugent \& Rhinard, 2016; Thomson \& Hosli, 2006) or amend it during the legislative procedure, thereby affecting the Council's voting rules (Fuglsang \& Olsen, 2009). Informal resources at the disposal of the Commission include its informational advantage vis-à-vis the co-legislators (e.g., König et al., 2007; Nugent \& Rhinard, 2016) or its brokerage position that allows it to play a crucial mediating role in the negotiations (Costello \& Thomson, 2013; Nugent \& Rhinard, 2016; Thomson \& Hosli, 2006). This combination of formal power and informational advantages provides the Commission with the potential to influence the outcome of negotiations (Costello \& Thomson, 2013; König et al., 2007).

On the other hand, others argue that the Commission only plays a limited role in trilogues. Since the Parliament and the Council interact directly from the beginning of the negotiations, they do not need to rely on the Commission for information on the preferences of their counterpart. As a result, the importance of the Commission's mediation role might decrease in trilogues, potentially also limiting its impact on the negotiations (Kreppel \& Oztas, 2017; Kurpas et al., 2008). Furthermore, the 
formal conditions to modify the Commission proposal are less strict during the first reading, as the co-legislators have neither time nor amendment limits. Thus, first readings are less favourable for the Commission (Cross \& Hermansson, 2017). Other aspects of trilogues, such as the involvement of the Commission's civil servants who often lack political skills (Fuglsang \& Olsen, 2009), or the Commission's preference for some change to none (Häge \& Kaeding, 2007), weaken its position in trilogues.

Overall, whether we assume that the Commission lost or preserved its role in trilogues, the relationship between the Commission and the co-legislators is an important factor in trilogues. Especially the congruence between the Commission's proposal and the co-legislators' preferences is crucial with regard to the amendments proposed by the Parliament and the Council to the legislative file (Bailer, 2014; Cross \& Hermansson, 2017). The more the co-legislators disagree with the policies in the proposal, the more they try to modify it. Conversely, research has shown that the proximity of their positions to the Commission's proposal increases their bargaining success (Costello \& Thomson, 2013; Franchino \& Mariotto, 2013). Another aspect of the institutional relationship that influences trilogues are the co-legislators' intra-institutional dynamics. Cross and Hermansson (2017), for example, have shown that these dynamics affect the capacity of the Commission to defend its proposals.

Few studies, however, have examined whether the Commission's intra-institutional dynamics influence trilogue negotiations as well. Looking not specifically at trilogues but at the overall legislative procedures in the EU; we know, for example, that the number of staff in the lead DG (Bailer, 2014) or the external consultation conducted by the Commission (Bunea \& Thomson, 2015) influence its ability to defend the proposal. Rauh (2020) finds that the capacity to anticipate the co-legislators' preferences, and thereby the number of amendments, varies across DGs depending on their experience and degree of coordination. Focusing on trilogues specifically, scholars observed that the Commission thoroughly prepares its trilogue mandates through an elaborate intra-institutional process (e.g., Page, 2012; Panning, 2021). Yet, so far these findings have not been linked with the subsequent trilogue negotiations. Nevertheless, those findings suggest that we should not only relax the assumption of the Commission as a unitary actor to better understand its behaviour and, following from that, the results of the EU legislative process, but that we should also pay more attention to the influence of the Commission's intra-institutional dynamics on trilogue negotiations and, thus, trilogue outcomes.

\section{How the Commission's Intra-Institutional Disagreements May Influence Trilogue Amendments}

To approach the puzzle whether the Commission's intra-institutional disagreements affect the number of the co-legislators' amendments, we develop three hypotheses regarding this effect of intra-institutional Commission dynamics. The first hypothesis considers potential effects of intra-institutional conflict in the Commission on the number of amendments submitted by the co-legislators during trilogues. The second and third hypotheses look at the effects of potential disagreements with the previous and subsequent Colleges on the number of adopted amendments.

\subsection{Intra-Institutional Conflicts during Internal Decision-Making}

The Commission is not a unitary actor. On the contrary, each DG and commissioner respectively prefers different policy outcomes (Ershova, 2019; Killermann, 2018). However, as discussed, the final decisions about legislative proposals are taken collegially in the Commission. In other words, all commissioners should agree with the decisions and, in turn, all commissioners are collectively responsible for them. This principle of collegiality implies that, in the case of disagreement within the College, decisions are likely to be a compromise among the different positions (Ershova, 2019; Wonka, 2008). Thus, all commissioners must make concessions and, thereby, will agree to a greater or lesser extent with the resulting College decision.

Since actors inside the Commission behave strategically to assert their preferences (Hartlapp et al., 2014), conflict may occur between different DGs and commissioners alike about the form and content of a legislative proposal. While the lead DG is in the most favourable position to defend its preferences, the College always takes the final decision. This "shadow of the vote" necessitates the integration of the positions of other DGs, as 'the threat to take a proposal to the College allows other commissioners to effectively restrict the political leeway of formally responsible commissioners' (Wonka, 2008, p. 1158). To this end, the Commission has developed a sophisticated system of preparatory bodies where DGs, cabinets, and commissioners discuss proposals under negotiation in trilogues to ensure that diverging preferences and suggestions are taken into account (Page, 2012; Panning, 2021).

Hence, the preference of the lead DG might deviate from the position expressed in the proposal approved by the College. In such cases, Commission negotiators in trilogues must defend a position that might differ from their own and, consequently, with which they do not fully agree. They therefore have incentives to try to steer the negotiations towards their own preferences, or, at least, to not support the adopted Commission proposal wholeheartedly. Although the preparatory bodies of the Commission agree on a mandate for the Commission negotiators (Page, 2012; Panning, 2021), trilogues are not only secluded and thus difficult to monitor, but expost sanctions are difficult for the Commission, since it lacks decision-making power. Delreux and Laloux (2018) 
observed such a situation: Their interviewees suggested that the lead DG, representing the Commission in trilogues, supported several co-legislators' amendments that were more in line with its own preferences than the original Commission proposal, which was the result of intra-institutional compromises.

Similarly, the diverging views of Commission actors also imply that the Commission may be less able to anticipate what is acceptable for the co-legislators. Having different standpoints, DGs may interpret the co-legislators' preferences differently, or may be more interested in defending certain policies than in anticipating the co-legislators' preferences (Rauh, 2020). In both cases, the fact that the proposal is based on a compromise decreases the likelihood of accurate anticipation. In the absence of conflicts, the Commission faces fewer obstacles in estimating the co-legislators' views. Hence, we expect:

h1: If the intra-institutional decision-making inside the Commission is conflictual, the number of amendments by the co-legislators to a legislative proposal increases.

\subsection{Potential Disagreements with the Previous and Subsequent College of Commissioners}

Not only conflicts within a College, but also potential disagreements with the previous or subsequent College may have an impact on the number of amendments. The preferences of commissioners decisively shape the positions of their DGs (Thomson, 2011; Wonka, 2007). However, it is likely that new commissioners set different priorities compared to their predecessors (Dinan, 2016). At the same time, EU legislative decision-making is often a lengthy process, such that commissioners frequently inherit proposals from their predecessors. In such cases, it is possible that the new lead commissioner does not fully support the proposal in the form adopted by their predecessors. Consequently, Commission representatives in trilogues may have an incentive not to defend these proposals as much as they could, resulting in an increased number of accepted amendments. Hence, the second hypothesis:

h2: Proposals issued by the previous Commission are more likely to be amended.

Consequently, when nearing the end of a Commission's term, the incumbent commissioner in charge may anticipate that their successor will not defend their proposals, which are still under negotiation, to the same extent as they would have. Therefore, they may want to conclude as many trilogues as possible before the end of the mandate to close the deal before a new Commission takes office. For the sake of speeding up the negotiation process, the lead commissioner, therefore, may be willing to make more concessions, or to propose different solutions more acceptable to the co-legislators. In other words, the commissioners may prefer to close a file in their term by accepting more amendments over risking even more modifications to their proposals when handing over to a new Commission. Accordingly, we expect that the less time Commission negotiators have to finish negotiations, the more they are willing to concede to speed up a file's adoption. This effect of anticipation can be observed with regard to the issuing of Commission proposals: The Commission initiates more proposals around the end of its term (Kovats, 2009). Accordingly, we hypothesise:

h3: The closer the end of a Commission's term, the more proposals are amended by the co-legislators before the final adoption.

\section{Data}

We measure the dependent variable, that is, the extent to which a Commission proposal is amended by the colegislators, using DocuToads, a minimum editing distance algorithm that was specifically developed to quantify the extent of amendments made to Commission proposals in the resulting legislative act (Cross \& Hermansson, 2017). Minimum edit distance algorithms quantify the degree of (dis)similarity of two texts by calculating the 'minimum number of editing operations required to transform one [text] into another' (Hermansson \& Cross, 2016, p. 10). Specifically, DocuToads considers four types of editing operations: deletion, insertion, substitution, and word transposition. In turn, the minimum number of these operations required to transform Commission proposals into final acts indicates the substantial amount of changes made between versions of the texts (Hermansson \& Cross, 2016).

Not only is the validity of this method theoretically justified by its creators, but, more importantly, the reliability of the algorithm's results has been confirmed by replicating existing studies on amendment tracking (Hermansson \& Cross, 2016) and comparing it with the results of qualitative case studies on EU legislative decision-making (Laloux \& Delreux, 2018). This last point explains our choice to use DocuToads instead of other text reuse methods (e.g., Gava et al., 2021). Unlike other algorithms, DocuToads was specifically developed to study amendments to Commission proposals and its validity for this purpose has thus been confirmed by other studies of the EU legislative process. Thus, we can be confident that it works as we expect it to, without the need for further verification, which might be less the case for methods developed for other contexts. Still, an important limitation of this approach is that it only considers the relative magnitude of the changes made and not their substantive meaning. Since we are interested in the former, this limitation is acceptable. Nevertheless, it should be kept in mind when interpreting the results. 
In line with the argument of Laloux and Delreux (2020) that in many important respects the recitals are an integral part of the legislative act, alongside the articles themselves, and that consequently amendments to them should be taken into account, we use the whole body of the legislative act, i.e., the recitals and the articles of the proposal. To compare between legislative files of different length the distance between a Commission proposal and the final compromise was standardised, dividing the number of editing operations by the total number of words in the Commission proposals. The degree of modification between the Commission proposal and the final legislation was measured on 216 early agreements negotiated and adopted on first reading between December 2012 and 2019. Noteworthy, as our study focuses on trilogues, we did not select trivial adoption, for which no negotiation is needed because the legislators already agree. Moreover, our dataset only includes first reading agreements, which means that our findings are not necessarily applicable to trilogues leading to early second reading adoption. Yet, this decision is justified by the fact that it enables controlling for differences between first and early second reading, especially since the latter is rarer (for a discussion on this point see Laloux, 2020).

Turning to the independent variables, we use two proxies to measure whether conflict occurred during the internal decision-making of the Commission (h1). The first proxy is College adoption of a proposal by oral or written procedure. A proposal is adopted by written procedure when there is no disagreement between commissioners that would need a debate in the College (Osnabrügge, 2015). Conversely, oral procedures concern sensitive issues for which disagreements must be settled at College meetings (Hartlapp et al., 2014). The use of oral procedures therefore indicates a higher level of intra-institutional conflict (Killermann, 2018). The mode of decision for each proposal is available on EUR-Lex. The second proxy is the number of DGs involved in the drafting of the proposal, as identified in the impact assessment accompanying a proposal. DGs, which are not responsible for a proposal, can contribute to the drafting thereof through inter-service coordination (Blom-Hansen \& Senninger, 2021; Panning, 2021). While every DG can participate, none is compelled to do so. Hence, arguably, they participate only when they are interested in a file. The number of participating DGs is therefore an indication of the extent of diverging interests within the Commission regarding the proposal.

To determine the effect of the previous Commission's adoption (h2), we use a dichotomous variable measuring whether the Commission issuing the act was the same as the one under which the legislation was adopted. Time before the end of term (h3) is calculated by the number of days between the last trilogue and the end of term of the Commission in charge. The date of the last trilogue was retrieved from the Committee of the Permanent Representatives of the Governments of the
Member States to the European Union (Coreper) briefings of the negotiations, which are available in the public register of Council documents.

We also control for several variables. First, we control for the difference between the Commission proposal and the trilogue mandates of the Parliament and the Council. Since the co-legislators have the decision-making power, such a difference is a crucial indicator of the number of amendments to a proposal (Bailer, 2014; Kreppel, 2018). In fact, controlling for the difference is necessary to test whether conflicts within the Commission have an impact on trilogues and not merely on the Commission's ability to anticipate the co-legislators' preferences (for a more detailed discussion see Rauh, 2020). The distance between each co-legislator's position and the Commission proposal is also determined with the DocuToads algorithm. Following Laloux and Delreux (2018), co-legislators' positions were collected from their public document registry. Specifically, we used the legislators' trilogue mandates. These documents contain the changes they officially wish to make to the Commission's proposals. Where the mandates contained only a list of amendments, we manually added them to the proposals in order to have comparable documents.

Second, following Bunea and Thomson (2015), we control for the number of recitals as a proxy for the level of information intensity of a file, i.e., 'the level of specialist technical expertise required to participate in policymaking' (Bunea \& Thomson, 2015, p. 522). When negotiating with a high level of information intensity, the co-legislators must rely more on the technical expertise of the Commission, which thereby enjoys more leverage over the outcome. Eventually, we also control for whether the negotiated act was a directive or not, and for the College that negotiated the files.

Third, we also control for the scope of the proposal, that is 'the extent to which policy effects are spread out over multiple policy fields' (Van Ballaert, 2017 , p. 410). This allows us to differentiate between issues that require several actors to cooperate and issues in which several actors are interested and therefore want to participate. We measure the scope by the number of EuroVoc descriptors (Van Ballaert, 2017).

\section{So, Do They Defend Alike Proposals They Disagree with?}

We measured our variables for a sample of 216 trilogue negotiations, that is, all the trilogues conducted and adopted as early agreements between 2012 and 2019. In 2012, the EP reformed its rules of procedure regarding trilogue negotiations, which we expect to have affected the conduct of trilogues as it led to more institutionalized practices. The end date was determined by the start of our analysis. On this basis, we tested our hypotheses by means of multiple regression analyses. Figure 1 shows the distribution of our dependent variable. Since our original variable was extremely right-skewed, we 


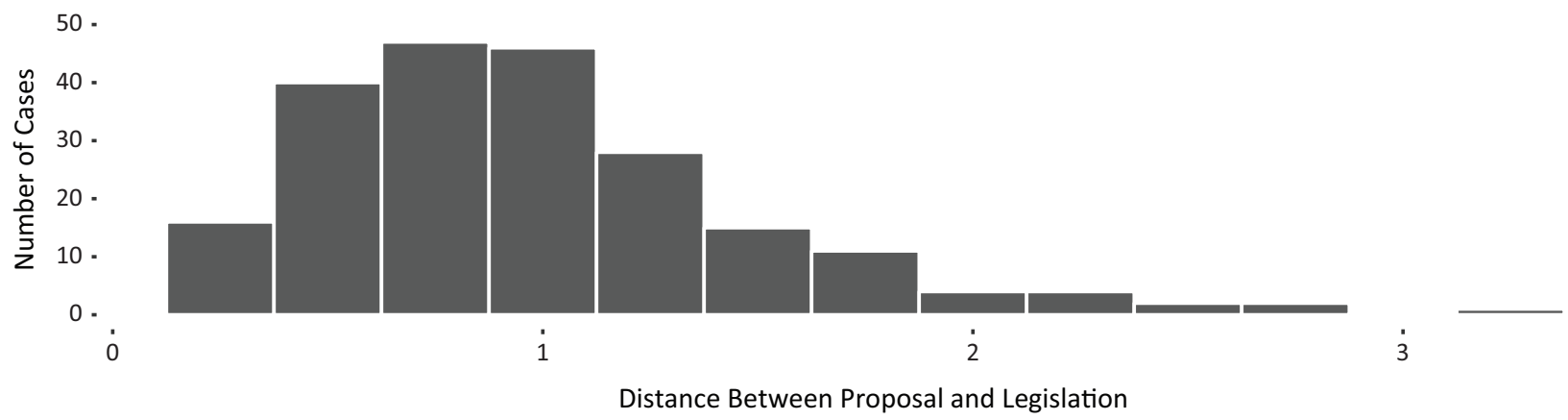

Figure 1. Distribution of the dependent variable.

used its logarithm in the analysis, which enabled us to conduct the ordinary least squares (OLS) regressions without violating its assumptions. As a robustness check, we also conducted robust regressions, more precisely, M-estimators using Tukey's biweight (BW) function (Baissa \& Rainey, 2020). The results of the robust regressions can be found in the Supplementary File of the article, and largely confirm those of the OLS. Table 1 presents the results of the regressions. We conducted two models, Model 1 with only the independent variables, adding the control variables in Model 2.

As the table shows, all variables in Model 1 are significant, except the number of days remaining until the next Commission (h3). Model 1 therefore confirms that, as expected, conflicts within the Commission and relationships with the previous College have an effect on the amendments adopted by the co-legislators. It is noteworthy that all the significant variables go in the

Table 1. Regressions analysis.

\begin{tabular}{|c|c|c|}
\hline & (1) & $(2)$ \\
\hline Decision: written & $\begin{array}{l}-0.265^{* * *} \\
(0.079)\end{array}$ & $\begin{array}{c}-0.022 \\
(0.056)\end{array}$ \\
\hline Number of DGs consulted & $\begin{array}{l}0.019 * * * \\
(0.006)\end{array}$ & $\begin{array}{l}0.009 * * \\
(0.004)\end{array}$ \\
\hline Number of days to end of term & $\begin{array}{c}-0.0003^{*} \\
(0.0001)\end{array}$ & $\begin{array}{c}-0.0002 * \\
(0.0001)\end{array}$ \\
\hline Issued by a different college & $\begin{array}{c}0.274^{* *} \\
(0.123)\end{array}$ & $\begin{array}{c}0.121 \\
(0.084)\end{array}$ \\
\hline Directive & & $\begin{array}{c}0.027 \\
(0.053)\end{array}$ \\
\hline Number of recitals & & $\begin{array}{c}0.001 \\
(0.002)\end{array}$ \\
\hline Distance with EP mandate & & $\begin{array}{l}0.431^{* * *} \\
(0.06)\end{array}$ \\
\hline Distance with Council mandate & & $\begin{array}{l}0.775^{* * *} \\
(0.078)\end{array}$ \\
\hline Scope & & $\begin{array}{c}0.009 \\
(0.010)\end{array}$ \\
\hline Constant & $\begin{array}{l}0.045^{* * *} \\
(0.108)\end{array}$ & $\begin{array}{l}-0.861^{* * *} \\
(0.102)\end{array}$ \\
\hline Observations & 216 & 216 \\
\hline $\mathrm{R}^{2}$ & 0.164 & 0.650 \\
\hline Adjusted $\mathrm{R}^{2}$ & 0.148 & 0.636 \\
\hline Residual Std. Error & $\begin{array}{l}0.517 \\
(d f=211)\end{array}$ & $\begin{array}{c}0.338 \\
(d f=207)\end{array}$ \\
\hline F Statistic & $\begin{array}{c}10.342 * * * \\
(d f=4 ; 211)\end{array}$ & $\begin{array}{r}47.973 * * * \\
(\mathrm{df}=8 ; 207)\end{array}$ \\
\hline
\end{tabular}

Notes: ${ }^{*} p<0.1,{ }^{* *} p<0.05,{ }^{* * *} p<0.01$, unstandardized effect, standard error in parenthesis. 
directions we expected. Conflicts increase the extent to which Commission proposals are modified. Similarly, proposals issued by the previous Commission are amended more on average. Eventually, as expected by h3, the more time remains in the term of one commissioner, the less a proposal will be modified. Those results suggest that, as expected by h3, conflicts in the Commission have an impact on the fate of proposals.

However, while interesting, those results cannot account for the effect of conflict on the capacity of the Commission to defend its proposals in trilogues. Indeed, when taking the control variables out of the models, one could interpret the findings in the sense that internal conflicts prevent the Commission from correctly anticipating the preferences of the co-legislators. Only by controlling for the accuracy of this anticipation, i.e., the distance between the proposal and the positions of the co-legislators, can one assess whether conflicts within the Commission affect trilogue negotiations after a pro-
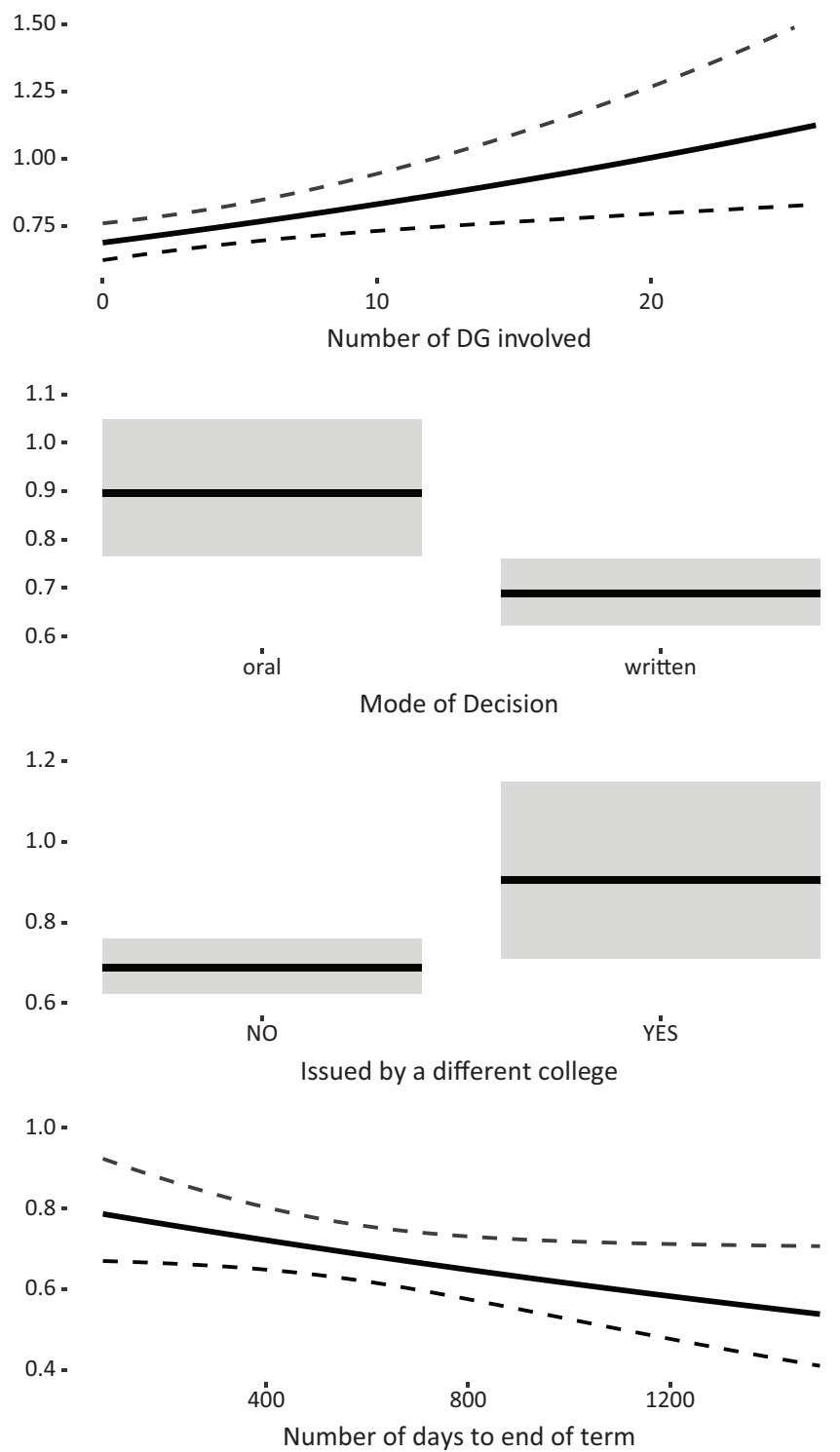

posal has been issued. Therefore, testing our hypotheses requires including those controls.

To that end, Model 2 controls for those distances together with the other control variables. As can be seen in Table 1, adding those variables changes the picture: Only the number of DGs consulted (h1) remains significant among the independent variables. In other words, we do not find evidence that potential disagreement with the previous (h2) or subsequent (h3) Commission increases deviation, nor that the mode of decision does so (h1). Those results suggest that these now nonsignificant variables might influence how co-legislators' preferences are anticipated when the Commission formulates its proposals, but not the role of the Commission in the ensuing trilogue negotiations. Figure 1 shows the marginal effects for all the independent variables, before and after the inclusion of the control variables. Regarding the control variables, unsurprisingly, the distance to the two co-legislators significantly increases the number of
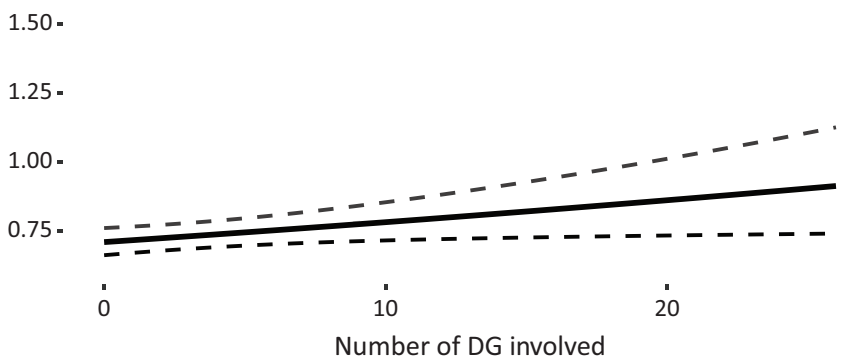

1.1 .

1.0

0.9 .

0.8 .

0.7 .

0.6 .

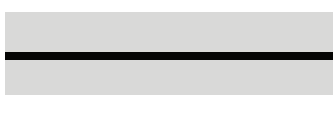

oral

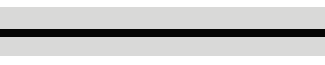

written

Mode of Decision

1.2

1.0

$0.8=$

0.6 .
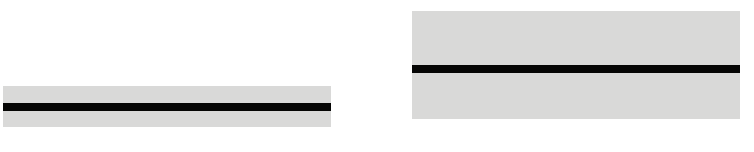

N'O

Y'ÉS

Issued by a different college

1.0

0.8

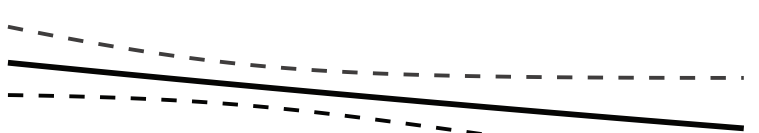

0.6 .

0.4

Figure 2. Marginal effects of the independent variables without and with controls. 
amendments, but neither the number of recitals nor the scope has a significant effect.

In sum, of all the hypotheses only h1 is partially confirmed. Only the number of DGs consulted is significant, while the mode of decision is not. One possible explanation for this difference is that the range of intra-institutional preferences is more important than the intensity of conflicts. These results are in line with, for example, the findings of Panning (2021) about intrainstitutional Commission dynamics. While the number of DGs measures the number of different interests involved in the Commission process, the choice of decision mode determines whether these differences are so intense that they need to be settled at the highest level, i.e., in the College. Another possible explanation is that, if an actor has a good opportunity to slack, it is enough to have conflicting preferences with its institution, regardless of the intensity of this conflict (Delreux \& Adriaensen, 2017).

\section{Conclusion}

The purpose of this article has been to examine the effect of intra-institutional conflicts in the Commission on the number of the amendments to the Commission's legislative proposal agreed by the co-legislators in trilogues. We hypothesized that such conflicts increase the number of amendments, as the lead commissioner, who is responsible for defending the proposal in trilogues, may not wholeheartedly defend the Commission's proposal. This assumption results from the fact that the decisions of the College are taken collectively, likely resulting in a compromise decision. In the case of disagreements, compromise decisions logically imply concessions on the part of the commissioners (Bellamy et al., 2012) and therefore do not fully correspond to the preferences of the lead commissioner nor, probably, of any commissioner in the College.

Furthermore, we assumed that a lead commissioner may not fully support a proposal if they are member of a new College, but they have to finalise trilogues that remain open from the previous Commission. As they have inherited the file under negotiation, they may be willing to accept more amendments to the original proposal, since they did not decide on its content. Relatedly, we also expected that a lead commissioner prefers to avoid such a situation. Therefore, they may accept more amendments if the term of the College is nearing its end, as they want to finalise negotiations under their mandate to not leave control to the successors. In other words, we have hypothesised that both the fact that a file was issued by a College other than the one that adopts it and the proximity of the end of a College increase the number of amendments.

We tested our hypotheses on a sample of 216 trilogue negotiations conducted between 2012 and 2019. It is important to note that we controlled for the distance between the proposals and the positions of the co-legislators to ensure that our hypotheses worked as expected, that is to say, that the effect of the conflict was not due to a lack of anticipation on the part of the Commission. Running the model without control variables, all the independent variables were significant in the expected direction. However, after adding the controls, we only found mixed evidence regarding the effect of intra-institutional conflict in policy formulation, and no evidence of an effect of the relationship with other Colleges, either preceding or following. Looking at intrainstitutional conflicts, the number of DGs involved in the process was significantly related to the extent of the amendments adopted in trilogues. The mode of decisionmaking within the College, however, was not significant. Consequently, these results suggest that the extent of intra-institutional conflicts in the Commission are more important than their intensity.

All taken together, our findings make several important contributions to understanding the hitherto neglected role of the Commission in trilogues, as well as to the EU legislative process more generally. First, the effects of variables in the model without control variables suggest that conflicts within the Commission and with other Colleges are important for the Commission's ability to foresee the preferences of the co-legislators. Being able to foresee the co-legislators' preferences is an essential ability for the Commission when developing and writing its legislative initiatives (Bunea \& Thomson, 2015; Häge \& Toshkov, 2011). While our findings changed insignificantly after adding control variables, it is possible that disagreements within or between different Colleges increase in importance with the increasing politicisation and presidentialisation of the Commission. If such developments would have negative implications for the Commission's ability to foresee preferences, not only would this impact one of the most central Commission tasks but also impact the subsequent legislative negotiations and thereby the efficiency of the EU legislative decision-making.

Second, commissioners do not appear to defend the proposals adopted by their predecessors differently, nor do they appear to fear that this will happen to their own proposals. This may indicate that preferences do not vary much among commissioners, or that commissioners do not have as much power in the formulation of proposals. Certainly, however, it complements previous findings regarding the thorough intra-institutional preparation of the Commission's trilogue mandates (e.g., Panning, 2021). Our findings suggest that the relevant actors abide by the mandate even if it was issued by a previous College, and that predecessors trust in this abidance of their successors. This may not come as a surprise if we take into consideration that, while the political level of the Commission (that is the commissioners and their cabinets) change every five years, the officials of the technical level (DGs and services), who assist the commissioners and prepare the original draft proposals, do not change (Hartlapp et al., 2014). 
From a normative perspective, this raises the issue of potential discontinuity in EU decision-making (König, 2007). That is, the fact that the decisions of legislative actors, in our case the content of legislative proposals, commit their successors even though their preferences change, thus hindering the possibility of policy revisions in line with those new preferences. If this is the case, questions regarding the possibility of Commission control, both by the co-legislators as well as by member states or EU citizens arise. For example, why select a Commission president through the Spitzenkandidaten procedure to make it politically more accountable if a change of College may not make such a big difference? Our findings may be a first indication in this direction, but future research will have to examine this possibility in greater detail.

Finally, the fact that the range of internal preferences matters to the Commission in trilogues has several implications. First, it contributes to the debate about whether or not the Commission has power in trilogues. So far, the Commission is often presented as a mediator between the Parliament and the Council in trilogues. Yet, if the intra-institutional dynamics within the Commission are important for trilogue outcomes beyond the anticipation of the co-legislators' preferences, the Commission may well have more influence in trilogues than assumed by existing research. To put it simply, this suggests that the Commission's representatives in trilogues could, to some extent, influence the outcome of negotiations. Hence, we conclude that the Commission's preferences must be taken into account to understand the outcomes of trilogues, that is EU legislation. If so, this would have normative consequences, as the Commission's legitimacy in legislative negotiations rests in part on its role as a neutral facilitator (Tsakatika, 2005). Therefore, if the Commission representative in trilogues promotes a particular position, which may, in case of intra-institutional disagreements, differ from the Commission mandate, one could question this legitimacy. In any case, this calls for more research on the Commission's role and influence in trilogues. For example, how can it influence trilogue negotiations if we keep in mind that it has no formal decisionmaking power? Does the Commission rely rather on formal or informal means to persuade the Parliament and the Council of its arguments?

Such results also have implications for our knowledge of the internal workings of the Commission. If the lead commissioners were indeed able to promote their positions in trilogues to the detriment of the College's proposal, this would mean that the Commission could very well have its own 'relais actors issues.' In other words, the informalisation of EU legislative decision-making could have had an impact on the intra-institutional balance of power within the Commission by favouring actors involved in trilogues. As in the case of the co-legislators, such a bias would be problematic, since the Commission as a whole is not only tasked with promoting the EU's general interest (according to the Article 17 (1) of the Treaty on European Union) and, therefore, collegially responsible for it, but its legitimacy is indirectly based on its representativity (Wille, 2012). Hence, this potential agency cost warrants further research on the delegation to representatives in trilogues within the Commission, on the possibility of agency slack from those representatives, and on the way, they are controlled during negotiations. Moreover, this also raises questions about both the conditions under which this slack is possible and about the kind of conflicts that induce slack.

Looking at the aim of this thematic issue, this would not only mean that the Commission's preferences matter for the output of the OLP. Moreover, the informal rule changes resulted in outputs closer to the preferences of the lead commissioner in the event of disagreement within the College. In other words, the shift to informal negotiations enables the lead commissioner to exert more influence on the outcome of the legislative process by modifying the College's proposals, which may not have been possible under the formal procedure. In sum, and to return to the quote from Kreppel (2018) that we cited in the introduction, our results underline that a more thorough discussion of the Commission's role in early agreements is necessary to better understand both the processes within trilogues as well as within the Commission. Therefore, our findings strongly call for putting the spotlight of trilogue research not only on Parliament and Council but also on the Commission as the third of three trilogue parties.

\section{Acknowledgments}

The authors thank the participants of the two workshops "Interinstitutional Power Dynamics in the European Decision-Making Process: An Analysis of the Impact of Rule Change on Policy Outputs" at the 2020 and 2021 ECPR Joint Sessions of Workshops, the two editors of the thematic issue, and the three anonymous referees of the journal for their valuable input and comments.

\section{Conflict of Interests}

The authors declare no conflict of interests.

\section{Supplementary Material}

Supplementary material for this article is available online in the format provided by the author (unedited).

\section{References}

Bailer, S. (2014). An agent dependent on the EU member states? The determinants of the European Commission's legislative success in the European Union. Journal of European Integration, 36(1), 37-53.

Baissa, D. K., \& Rainey, C. (2020). When blue is not best: Non-normal errors and the linear model. Political Science Research and Methods, 8(1), 136-148. 
Becker, S., Bauer, M. W., Connolly, S., \& Kassim, H. (2016). The Commission: Boxed in and constrained, but still an engine of integration. West European Politics, 39(5), 1011-1031.

Bellamy, R., Kornprobst, M., \& Reh, C. (2012). Introduction: Meeting in the middle. Government and Opposition, 47(3), 275-295.

Blom-Hansen, J., \& Senninger, R. (2021). The Commission in EU policy preparation. JCMS: Journal of Common Market Studies, 59(3), 625-642.

Bunea, A., \& Thomson, R. (2015). Consultations with interest groups and the empowerment of executives: Evidence from the European Union. Governance, 28(4), 517-531.

Bürgin, A. (2017). Internal coordination and legitimation strategies: Assessing the influence of individual commissioners in the policy formulation process. Journal of European Integration, 39(1), 1-15.

Burns, C. (2014, June 5-7). The European Commission as a policy actor under the ordinary legislative procedure [Paper presentation]. 7th Pan-European Conference on the European Union, The Hague, Netherlands.

Chalmers, A. W. (2014). In over their heads: Public consultation, administrative capacity and legislative duration in the European Union. European Union Politics, 15(4), 595-613.

Costello, R., \& Thomson, R. (2013). The distribution of power among EU institutions: Who wins under codecision and why? Journal of European Public Policy, 20(7), 1025-1039.

Cross, J. P., \& Hermansson, H. (2017). Legislative amendments and informal politics in the European Union: A text reuse approach. European Union Politics, 18(4), 581-602.

Delreux, T., \& Adriaensen, J. (2017). Introduction. Use and limitations of the principal-agent model in studying the European Union. In T. Delreux \& J. Adriaensen (Eds.), The principal agent model and the European Union (pp. 1-34). Palgrave Macmillan.

Delreux, T., \& Laloux, T. (2018). Concluding early agreements in the EU: A double principal-agent analysis of trilogue negotiations. Journal of Common Market Studies, 56(2), 300-317.

Dinan, D. (2016). Governance and institutions: A more political commission. JCMS: Journal of Common Market Studies, 54(S1), 101-116.

Ershova, A. (2019). The watchdog or the mandarin? Assessing the impact of the directorates general on the EU legislative process. Journal of European Public Policy, 26(3), 407-427.

European Parliament. (2019). Activity report on the ordinary legislative procedure of 4 July 2014-31 December 2019 (8th parliamentary term).

Franchino, F., \& Mariotto, C. (2013). Explaining negotiations in the conciliation committee. European Union Politics, 14(3), 345-365.

Fuglsang, N., \& Olsen, K. B. (2009). Staying in the Loop-
The Commission's role in first reading agreements (No. 25). European Policy Institutes Network (EPIN).

Gastinger, M. (2017). Effects of contestation within a collective agent in EU trade policy-making. In T. Delreux \& J. Adriaensen (Eds.), The principal agent model and the European Union (pp. 181-202). Springer.

Gava, R., Jaquet, J. M., \& Sciarini, P. (2021). Legislating or rubber-stamping? Assessing parliament's influence on law-making with text reuse. European Journal of Political Research, 60(1), 175-198.

Häge, F. M., \& Kaeding, M. (2007). Reconsidering the European Parliament's legislative influence: Formal vs. informal procedures. Journal of European Integration, 29(3), 341-361.

Häge, F. M., \& Toshkov, D. (2011). Anticipating resistance: The effect of member state preferences on the European Commission's agenda-setting activity (Limerick Papers in Politics and Public Administration, No. 1). University of Limerick.

Hartlapp, M., Metz, J., \& Rauh, C. (2013). Linking agenda setting to coordination structures: Bureaucratic politics inside the European Commission. Journal of European Integration, 35(4), 425-441.

Hartlapp, M., Metz, J., \& Rauh, C. (2014). Which policy for Europe? Power and conflict inside the European Commission. Oxford University Press.

Hermansson, H., \& Cross, J. P. (2016). Tracking amendments to legislation and other political texts with a novel minimum-edit-distance algorithm: DocuToads. ArXiv. https://arxiv.org/abs/1608.06459

Killermann, K. (2018). The influence of commissioners' characteristics on the EU's legislative process [Doctoral thesis, University of Twente]. University of Twente Research Information. https://research. utwente.nl/en/publications/the-influence-ofcommissioners-characteristics-on-the-eus-legisla

Kluger Dionigi, M., \& Koop, C. (2017). Investigation of informal trilogue negotiations since the Lisbon Treaty: Added value, lack of transparency, and possible democratic deficit (Contract No. CES/CSS/ 13/2016, 23284). The European Economic and Social Committee.

König, T. (2007). Discontinuity: Another source of the EU's democratic deficit? European Union Politics, 8(3), 411-432.

König, T., Lindberg, B., Lechner, S., \& Pohlmeier, W. (2007). Bicameral conflict resolution in the European Union: An empirical analysis of conciliation committee bargains. British Journal of Political Science, 37(2), 281-312.

Kovats, L. (2009). Do elections set the pace? A quantitative assessment of the timing of European legislation. Journal of European Public Policy, 16(2), 239-255.

Kreppel, A. (2018). Bicameralism and the balance of power in EU legislative politics. The Journal of Legislative Studies, 24(1), 11-33.

Kreppel, A., \& Oztas, B. (2017). Leading the band or just playing the tune? Reassessing the agenda-setting 
powers of the European Commission. Comparative Political Studies, 50(8), 1118-1150.

Kurpas, S., Grøn, C., \& Kaczyński, P. M. (2008). The European Commission after enlargement: Does more add up to less? CEPS.

Laloux, T. (2020). Informal negotiations in EU legislative decision-making: A systematic review and research agenda. European Political Science, 19(3), 443-460.

Laloux, T., \& Delreux, T. (2018). How much do agents in trilogues deviate from their principals' instructions? Introducing a deviation index. Journal of European Public Policy, 25(7), 1049-1067.

Laloux, T., \& Delreux, T. (2020). The origins of EU legislation: Agenda-setting, intra-institutional decisionmaking or interinstitutional negotiations? West European Politics. Advance online publication. https://doi. org/10.1080/01402382.2020.1836861

Nugent, N., \& Rhinard, M. (2016). Is the European Commission really in decline? JCMS: Journal of Common Market Studies, 54(5), 1199-1215.

Nugent, N., \& Rhinard, M. (2019). The 'political' roles of the European Commission. Journal of European Integration, 41(2), 203-220.

Osnabrügge, M. (2015). The European Commission and the implementation of its legislative programme. European Union Politics, 16(2), 241-261.

Page, E. C. (2012). Policies without politicians: Bureaucratic influence in comparative perspective. Oxford University Press.

Panning, L. (2021). Building and managing the European Commission's position for trilogue negotiations. Journal of European Public Policy, 28(1), 32-52.

Rasmussen, A. (2012). Twenty years of co-decision since Maastricht: Inter- and intrainstitutional implications. Journal of European Integration, 34(7), 735-751.

Rasmussen, A., \& Toshkov, D. (2013). The effect of stakeholder involvement on legislative duration: Consultation of external actors and legislative duration in the European Union. European Union Politics, 14(3), 366-387.

Rauh, C. (2019). EU politicization and policy initiatives of the European Commission: The case of con- sumer policy. Journal of European Public Policy, 26(3), 344-365.

Rauh, C. (2020). One agenda-setter or many? The varying success of policy initiatives by individual directoratesgeneral of the European Commission 1994-2016. European Union Politics, 22(1), 3-24. https://doi.org/ $10.1177 / 1465116520961467$

Ripoll Servent, A., \& Panning, L. (2019). Eurosceptics in trilogue settings: Interest formation and contestation in the European Parliament. West European Politics, 42(4), 755-775.

Roederer-Rynning, C., \& Greenwood, J. (2015). The culture of trilogues. Journal of European Public Policy, 22(8), 1148-1165.

Thomson, R. (2011). Resolving controversy in the European Union: Inputs, processes and outputs in legislative decision-making before and after enlargement. Cambridge University Press.

Thomson, R., \& Hosli, M. (2006). Who has power in the EU? The Commission, Council and Parliament in legislative decision-making. JCMS: Journal of Common Market Studies, 44(2), 391-417.

Tsakatika, M. (2005). Claims to legitimacy: The European Commission between continuity and change. JCMS: Journal of Common Market Studies, 43(1), 193-220.

Tsebelis, G. (2002). Veto players: How political institutions work. Princeton University Press.

Van Ballaert, B. (2017). The European Commission's use of consultation during policy formulation: The effects of policy characteristics. European Union Politics, 18(3), 406-423.

Wille, A. (2012). The politicization of the EU Commission: Democratic control and the dynamics of executive selection. International Review of Administrative Sciences, 78(3), 383-402.

Wonka, A. (2007). Technocratic and independent? The appointment of European Commissioners and its policy implications. Journal of European Public Policy, 14(2), 169-189.

Wonka, A. (2008). Decision-making dynamics in the European Commission: Partisan, national or sectoral? Journal of European Public Policy, 15(8), 1145-1163.

\section{About the Authors}

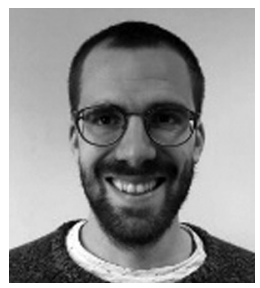

Thomas Laloux is a Fund for Scientific Research (F.R.S.-FNRS) Research Fellow at Institute of Political Science Louvain-Europe at the UCLouvain (Belgium). His main research interest lies in EU legislative decision-making and focuses more particularly on inter-institutional negotiations. He completed his PhD in 2021 and his work has appeared in the Journal of European Public Policy, Journal of Common Market Study, West European Politics and European Political Science.

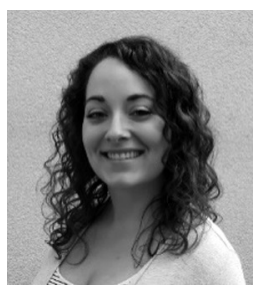

Lara Panning is a Doctoral Member of the Bamberg Graduate School of Social Sciences at the University of Bamberg (Germany). She researches informal negotiation processes at EU level with a focus on the European Commission and the European Parliament as well as the rise of populism and Euroscepticism. Her work has appeared in the Journal of European Public Policy, West European Politics and Politics and Governance. 